\title{
PENGEMBANGAN BUKU SISWA BERORIENTASI CHEMO- ENTREPRENEURSHIP (CEP) PADA MATERI IKATAN KIMIA SMA/MA KELAS X
}

\author{
Hamidah $^{\mathbf{1}^{*}}$ dan Agus Kamaludin ${ }^{1}$ \\ 1 Program Studi Pendidikan Kimia, Fakultas Sains dan Teknologi, \\ Universtas Islam Negeri Sunan Kalijaga, Jalan Laksda Adisucipto, Sleman, \\ Daerah Istimewa Yogyakarta, Indonesia \\ 'E-mail: hamidaharieska23@gmail.com
}

\begin{abstract}
ABSTRAK
Penelitian ini bertujuan untuk mengembangkan bahan ajar berupa buku siswa bermuatan ChemoEntrepreneurship (CEP) pada materi ikatan kimia SMA/MA kelas X. Model yang digunakan dalam proses pengembangan produk mengadaptasi model 4D (Define, Design, Development, dan Disseminate). Produk buku siswa ini divalidasi oleh satu dosen ahli materi, satu dosen ahli media, dan tiga peer reviewer. Kualitas produk dinilai oleh empat reviewer (guru kimia SMA/MA) dan direspon sepuluh siswa SMA/MA. Instrumen yang digunakan berupa lembar penilaian kualitas produk menggunakan skala Likert dan lembar respon siswa berupa angket menggunakan skala Guttman. Karakteristik buku yang dikembangkan yaitu terdiri atas ikatan kimia, geometri molekul, interaksi antarmolekul, dan tugas kewirusahaan pembuatan media MEc Bond, lilin aromaterapi, dan lampu lava. Penilaian kualitas buku siswa oleh empat reviewer mendapatkan persentase $86,32 \%$ dengan kategori Sangat Baik (SB) dan respon sepuluh siswa dengan persentase $96 \%$. Dari hasil tersebut dapat disimpulkan produk yang dikembangkan layak digunakan untuk proses pembelajaran di SMA/MA pada materi ikatan kimia.
\end{abstract}

Kata kunci: buku siswa, chemo-entrepreneurship, ikatan kimia.

\begin{abstract}
This study aims to develop teaching materials in the form of student book with Chemo-Entrepreneurship (CEP) value in chemical bonding concept for class X Senior High School. The model used for this research was adapted from 4D model (Define, Design, Development, and Disseminate). The produced student book was validated by one content expert lecturer, one media expert lecturer, and three peer-reviewers. Product quality was assessed by four reviewers (chemistry teachers in Senior High School) and responded by ten Senior High School students. The instrument used in this research was product quality assessment form using the Likert scale, and student response questionnaire using the Guttman scale. The characteristics of the books developed are consisted of chemical bonding, molecular geometry, intermolecular interactions, and entrepreneurship task i.e. producing media MEc Bond, lava lamps, and aromatherapy candles which are expected to foster the entrepreneurship spirit of students. Assessment of the student book quality by four reviewers received a percentage of $86.32 \%$ which is in the Very Good category and and the response of ten students with a percentage of $96 \%$. From these results it can be concluded that the products developed are suitable for use in the learning process in senior high school on chemical bonding concept.
\end{abstract}

Keywords: student book, chemo-entrepreneurship, chemical bonding.

DOI: https://doi.org/10.15575/jtk.v3i2.3795 


\section{PENDAhUluan}

Entrepreneurship telah muncul selama dua dekade terakhir ini sebagai salah satu kekuatan ekonomi yang paling ampuh di dunia (Kuratko, 2005). Oleh karena itu, semua negara termasuk Indonesia mulai berbenah memperbaiki kerangka kurikulumnya dengan memasukkan aspek ini ke dalam mata kuliah. Jumlah perguruan tinggi dan universitas yang menawarkan program yang berkaitan dengan kewirausahaan telah berkembang dari segelintir pada tahun 1970 menjadi lebih dari 1.600 pada tahun 2005 (Kuratko, 2005). Hal ini mengindikasikan bahwa memiliki jiwa entrepreneur merupakan salah satu hal penting saat ini. Bahkan, kewirausahaan (entrepreneurship) menjadi mata pelajaran wajib di Sekolah Menengah Atas (SMA). David Mc Clelland, seorang ahli psikologi asal Amerika menyatakan bahwa suatu negara dapat dikatakan makmur ketika sedikitnya terdapat $2 \%$ entrepreneur dari total penduduk yang ada (Ciputra, 2008). Badan Pusat Statistik (2017) juga mencatat tingkat pengangguran terbuka per Februari 2018 pada lulusan pendidikan Sekolah Menengah Atas (SMA) masih tinggi yaitu sebesar 7,19\% dari 6,87 juta orang (Kusuma, 2018).

Salah satu upaya yang dapat dilakukan untuk mengatasi pengangguran lulusan SMA adalah membekali siswa dengan keterampilan hidup (life skill) yang dapat memberikan kemampuan dan keberanian dalam menghadapi problematika kehidupan, kemudian secara kreatif menemukan solusi serta mampu beradaptasi untuk memenuhi tuntutan dan tantangan dalam kehidupan sehari-hari. Namun, dalam pelaksanaan life skill di sekolah masih tergolong kurang baik karena tidak menarik perhatian siswa (Widada, 2012). Salah satu bentuk keterampilan hidup yang akan membekali siswa dalam meningkatkan kualitas hidupnya adalah pendidikan kewirausahaan (Tohani, 2015).

Seseorang yang memiliki jiwa wirausaha adalah mereka yang di dalam kepribadiannya telah terinternalisasikan nilai-nilai kewirausahaan. Nilai-nilai kewirausahaan yang dikembangkan antara lain inovasi, kreatif, berpikir kritis, eksplorasi, komunikasi, kemandirian, dan memiliki etos kerja. Soemanto (2006) menyatakan bahwa pendidikan kewirausahaan berusaha untuk menjawab manusia yang berkualitas guna menjadikan manusia bukan hanya mampu mencari pekerjaan, melainkan untuk mengembangkan sumber daya manusia yang mampu menciptakan pekerjaan bagi dirinya, atau bahkan mampu menyediakan lapangan kerja bagi orang lain. Kendala yang dialami pada pengimplementasian pendidikan kewirausahaan yaitu pengelolaan yang kurang terkoordinir (Winarno, 2011) dan salah satu hambatan guru dalam mengelola kelas pembelajaran kewirausahaan adalah alokasi waktu yang sedikit dalam pembelajaran (Parwathi, dkk., 2017). Oleh karena itu, kompetensi kewirausahaan dapat tercapai dengan menyelipkan di mata pelajaran yang relevan dengan menggunakan berbagai metode pembelajaran yang membangun spirit kewirausahaan salah satunya adalah mata pelajaran kimia.

Dibanding dengan bidang yang lain, kimia sering terkesan lebih sulit, paling tidak pada tingkat dasar. Kimia memiliki perbendaharaan kata yang sangat khusus dan juga saat mempelajari kimia sama seperti mempelajari bahasa yang baru. Di sisi lain, kesan siswa ketika mempelajari kimia tersebut berpengaruh terhadap hasil belajarnya (Putri dkk., 2018). Berdasarkan hasil wawancara dengan siswa SMA di Yogyakarta, menyatakan bahwa pelajaran kimia masih sulit untuk dipahami karena terdapat beberapa materi kimia yang membutuhkan daya nalar yang tinggi. Salah satu materi yang dianggap sulit oleh siswa kelas $X$ adalah materi ikatan kimia. Hasil penelitian juga menunjukkan bahwa siswa mengalami kesulitan dalam mempelajari ikatan kimia (Haris \& Wahidah, 2007).

Kesulitan siswa terhadap pelajaran kimia dan banyaknya pengangguran lulusan SMA maka perlu adanya suatu pendekatan pembelajaran kimia yang mampu menarik minat siswa dalam mempelajari materi kimia sekaligus meningkatkan jiwa entrepreneurship siswa. 
Salah satunya pendekatan pembelajaran yang dapat digunakan adalah ChemoEntrepreneurship (CEP). CEP adalah suatu pendekatan pembelajaran kimia yang kontekstual yaitu dikaitkan dengan objek nyata sehingga siswa dapat mempelajari proses pengolahan suatu bahan menjadi produk yang bermanfaat, bernilai ekonomi, dan menumbuhkan semangat berwirausaha. Penggunaan pendekatan CEP pada mata pelajaran kimia akan lebih menyenangkan dan memberi kesempatan siswa untuk mengoptimalkan potensinya agar menghasilkan suatu produk (Supartono, 2006).

Konsep pendekatan Chemo-Entrepreneurship (CEP) ini dapat disampaikan dengan menggunakan bantuan media pembelajaran. Gagne dan Briggs mengatakan bahwa media pembelajaran meliputi alat secara fisik digunakan untuk menyampaikan isi materi pengajaran (Arsyad, 2011). Media pembelajaran dapat merangsang perhatian, minat, pikiran, dan perasaan siswa dalam kegiatan belajar untuk mencapai tujuan pembelajaran (Daryanto, 2010). Dalam pembelajaran, guru masih banyak menggunakan LKS (Lembar Kerja Siswa) sebagai media pembelajaran (Nugroho, 2015). LKS yang ada belum banyak menyediakan ruang bagi siswa untuk mengeksplorasi aktivitas belajarnya secara langsung (Isnanto, 2016) dan LKS belum menggunakan pendekatan yang dapat meningkatkan jiwa kewirausahaan siswa. Salah satu media pembelajaran lain yang dapat digunakan yaitu buku siswa bermuatan CEP karena buku siswa merupakan salah satu penunjang keberhasilan dalam pencapaian tujuan pembelajaran yang dapat dikemas dengan berbagai pendekatan sesuai dengan hasil yang akan dicapai (Rachmawati, 2004). Adanya panduan kewirausahaan dapat meningkatkan pemahaman atau hasil belajar dan meningkatkan minat kewirausahaan siswa (Prayitno dkk., 2016)

Menurut Trianto (2012) buku siswa merupakan buku panduan bagi siswa dalam kegiatan pembelajaran yang memuat materi pelajaran, kegiatan penyelidikan berdasarkan konsep, kegiatan sains, informasi, dan contoh-contoh penerapan sains dalam kehidupan sehari-hari. Buku siswa dapat digunakan siswa sebagai sarana penunjang untuk kelancaran kegiatan belajarnya di kelas maupun di rumah (Arsyad, 2011). Diharapkan dengan adanya bahan ajar berupa buku siswa pada materi ikatan kimia yang dikemas dengan pendekatan ChemoEntrepreneurship dapat meningkatkan pemahaman atau hasil belajar siswa pada materi ikatan kimia dan dapat menumbuhkan minat kewirausahaan.

\section{METODE PENELITIAN}

Penelitian ini merupakan penelitian pengembangan (Research and Development) yang bertujuan mengembangkan suatu produk baru serta mengetahui kualitas buku siswa yang telah dikembangkan. Menurut Sugiyono (2012) metode penelitian dan pengembangan adalah metode penelitian yang digunakan untuk menghasilkan produk tertentu, dan menguji keefektifan produk tersebut. Subjek penilai dalam penelitian pengembangan ini adalah empat orang reviewer (guru kimia SMA/MA) dan respon sepuluh orang siswa.

Prosedur pengembangan pada penelitian ini mengadaptasi model 4-D (four- $D$ model). Menurut Thiagarajan pengembangan produk ini meliputi tahap define (pendefinisian), design (perancangan), development (pengembangan), dan disseminate (diseminasi) (Sugiyono, 2012). Namun, dalam penelitian ini hanya sampai tahap development (pengembangan).

Tahap define (pendefinisian) bertujuan untuk menentukan dan mendefinisikan kebutuhankebutuhan di dalam proses pembelajaran serta mengumpulkan berbagai informasi yang berkaitan dengan produk yang akan dikembangkan. Langkah-langkah yang dilakukan adalah analisis awal, analisis siswa, analisis tugas, analisis konsep, dan analisis tujuan pembelajaran. 
Tahap design (perancangan) bertujuan untuk merancang buku siswa yang akan dikembangkan. Tahap ini meliputi pemilihan media, pemilihan format, pengumpulan referensi, pembuatan instrumen, dan pembuatan rancangan awal.

Tahap development (pengembangan) bertujuan untuk menghasilkan buku siswa yang sudah direvisi berdasarkan masukan dari validator.

Jenis data yang digunakan adalah data validasi produk dan data penilaian produk. Data validasi produk berupa saran, komentar dan masukan dari dosen ahli materi, dosen ahli media, peer review, dan reviewer (guru kimia SMA/MA). Sedangkan data penilaian produk berupa data kualitatif dan data kuantitatif.

Instrumen pengumpulan data yang digunakan dalam penelitian pengembangan ini adalah lembar validasi produk sebagai bahan pedoman dalam melakukan perbaikan bahan ajar berupa buku siswa dan lembar penilaian kualitas untuk reviewer (guru kimia SMA/MA) yang terdiri dari 6 aspek yaitu aspek kelayakan isi/materi, aspek kelayakan bahasa, aspek penyajian, aspek kegrafikaan, aspek karakteristik buku siswa, dan aspek ChemoEntrepreneurship (CEP) serta lembar respon siswa bertujuan untuk mengetahui respon siswa terhadap produk buku siswa berbasis Chemo-Entrepreneurship (CEP).

Teknik analisis data berupa data validasi dan data penilaian produk. Data validasi diperoleh dari hasil validasi produk. Data validasi berupa data kualitatif yang berisi saran dan masukan terhadap buku siswa yang dikembangkan. Hasil dari saran dan masukan tersebut digunakan sebagai perbaikan bahan ajar berupa buku siswa yang dikembangkan.

Data yang diperoleh dari reviewer (guru kimia SMA/MA) tentang kualitas buku siswa diolah dengan mengubah penilaian kualitatif menjadi kuantitatif (Sugiyono, 2012), kemudian mengubah nilai rerata skor tiap indikator (Widoyoko, 2011). Jumlah rerata skor tiap aspek selanjutnya diinterpretasikan menggunakan rumus konversi skor skala 5 (Sukardjo \& Lis, 2008). Tahap terakhir yaitu menghitung persentase keidealan kualitas bahan ajar berupa buku siswa secara keseluruhan untuk menentukan kualitasnya.

Data dari respon siswa dalam bentuk huruf diubah menjadi skor menggunakan skala Guttman, kemudian menghitung persentase skor rata-rata dari hasil penilaian, dan menghitung persentase keidealan respon siswa terhadap buku siswa secara keseluruhan.

\section{HASIL DAN PEMBAHASAN}

Penelitian ini bertujuan untuk mengembangkan bahan ajar berupa buku siswa bermuatan Chemo-Entrepreneurship (CEP) pada materi ikatan kimia SMA/MA kelas $X$. Bahan ajar dibuat melalui analisis tahap define, design, dan development. Pada tahap define diketahui bahwa di sekolah masih menggunakan LKS untuk pembelajaran dan belum ada buku siswa mata pelajaran kimia kelas $X$ yang menggunakan pendekatan kewirausahaan. Salah satu materi kimia di kelas $X$ yang sulit adalah ikatan kimia karena materinya bersifat abstrak sehingga dibutuhkan logika dan daya nalar yang tinggi untuk memahami. Oleh karena itu, bahan ajar yang dikembangkan dilengkapi pembuatan media pembelajaran yang dapat membuat materi ikatan kimia lebih kongkret dan dapat meningkatkan jiwa entrepreneurship siswa.

Tahap design, dihasilkan rancangan bahan ajar berupa buku siswa dengan menggunakan Microsoft Word 2010 ukuran kertas B5. Selain itu juga digunakan aplikasi Corel DRAW Graphics Suite $X 7$ untuk membuat cover, Chem Draw Profesional 15.0 dan ChemSketch untuk membuat rumus struktur Lewis serta Avogadro yang digunakan untuk menggambar bentuk molekul.

Langkah selanjutnya pada tahap define yaitu melakukan perancangan awal yang terdiri dari sampul, identitas buku, kata pengantar, daftar isi, petunjuk penggunaan buku, kompetensi, peta konsep, isi buku, tugas kewirausahaan, rangkuman, evaluasi, dan bagian penutup. 
Gambar sampul buku siswa bermuatan CEP dapat dilihat pada Gambar 1.
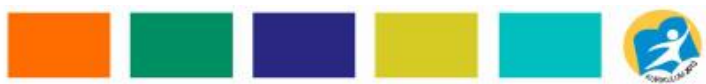

Buku Siswa

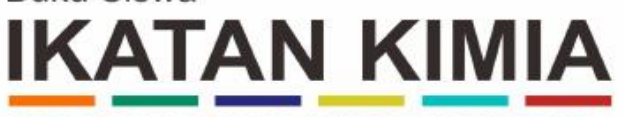

BERMUATAN CHEML-ENTREPRENEURSHIP

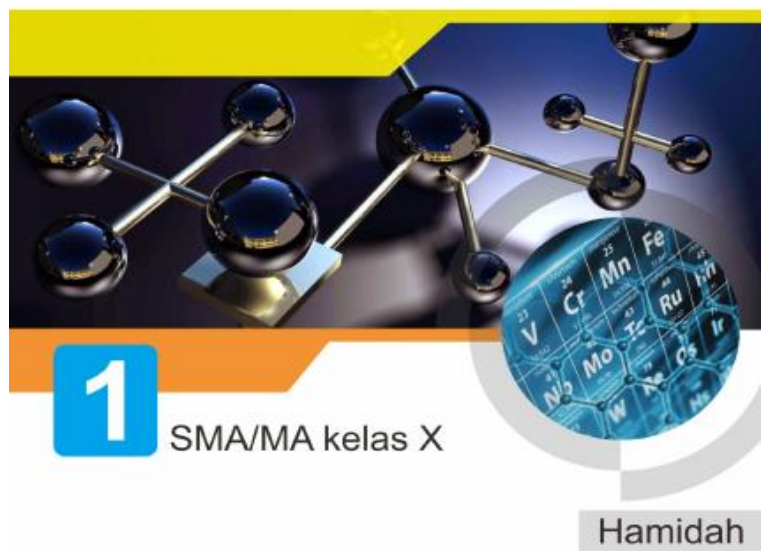

\section{Gambar 1. Sampul Buku Siswa}

Bagian isi terdiri atas tiga sub bab materi yaitu ikatan kimia, geometri molekul, dan interaksi antarmolekul. Tiga sub bab tersebut mengacu pada kurikulum kimia SMA agar dapat digunakan untuk pembelajaran di kelas. Di dalam subbab tersebut dilengkapi dengan contoh soal dan latihan untuk menguji pemahaman siswa tentang materi ikatan kimia.

Tugas kewirausahaan berupa tugas pembuatan media pembelajaran MEC Bond, lilin aromaterapi, dan lampu lava. Pemberian tugas kewirausahaan MEC Bond berkaitan dengan materi ikatan kimia terutama struktur Lewis. Siswa diajak untuk membuat media pembelajaran struktur lewis dari akrilik, karton atau kayu sehingga memudahkan dalam mempelajari materi struktur lewis. Melalui media ini siswa dapat belajar ikatan kimia terutama pada materi struktur lewis menggunakan media pembelajaran tiga dimensi yang akan membuat materi menjadi lebih konkret. Adapun bentuk fisik MEC Bond dapat dilihat pada Gambar 2. Media MEC Bond dijual dalam bentuk media pembelajaran. Lilin aromaterapi berkaitan dengan materi gaya antar molekul dan lampu lava berkaitan dengan materi kepolaran. Siswa diajak untuk membuat lilin aromaterapi dan lampu lava dengan dikemas yang menarik sehingga mempunyai nilai jual. Tugas kewirausahaan juga disertai dengan pembuatan anggaran dana untuk mengetahui rincian biaya yang digunakan dan keuntungannya.
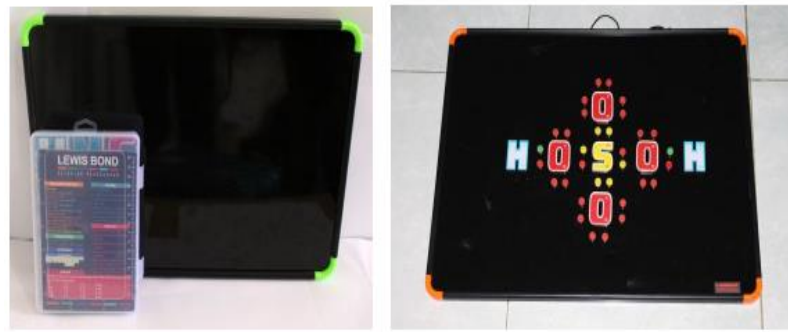

\section{Gambar 2. MEc Bond dari Akrilik}

Tugas produk kewirausahaan untuk pembuatan MEC Bond, lilin aromaterapi dan lampu lava pada buku siswa bermuatan CEP dapat dilihat pada Gambar 3, 4 dan 5.

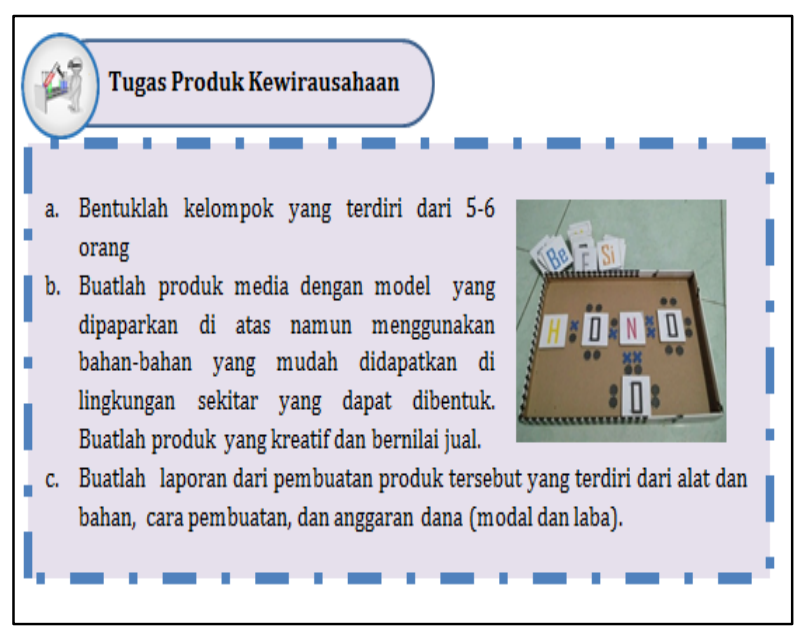

Gambar 3 Tugas Kewirausahaan MEc Bond 
Tugas Produk Kewirausahaan

$-1$

Bentuklah kelompok yang terdiri dari 5-6 orang!

Siapkanlah alat dan bahan-bahan yang diperlukan

Alat

Bahan

Parafin 25 gram

Asam stearat 2,5 gram

Gelas beker $100 \mathrm{~m}$

Termomete

Pengaduk

Botol akuades

Pewarna lilin/ dye 0,15 gram

Minyak nilam (10\%) $2 \mathrm{~mL}$

Benang lilin

Minyak essensial/lavender $2 \mathrm{~mL}$

Gelas/sloki

Plastik hias

Pita hias
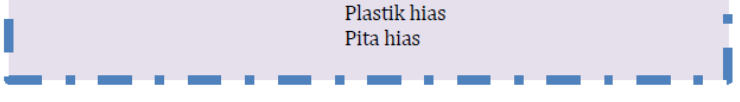

c. Langkah-langkah pembuatan lampu lava sebagai berikut:

Buatlah campuran pertama dengan cara panaskan asam stearat sampai suhu $55^{\circ} \mathrm{C}$ tambahkan pewarna lilin dan dipanaskan sampai suhu $65-70^{\circ} \mathrm{C}$. Selanjutnya aduklah sampai suhu menjadi $40^{\circ} \mathrm{C}$

Buatlah campuran ke-2 dengan cara panaskan parafin hingga suhu $50^{\circ} \mathrm{C}$ Kemudian aduklah menjadi satu campuran pertama dan kedua, tambahkan minyak essensial pada suhu $40^{\circ} \mathrm{C}$ serta minyak

nilam untuk mengikat minyak essensial.

Masukkan campuran hasil akhir kedalam gelas/sloki disertai pengadukan agar tidak terbentuk gelembung.

d. Buatlah laporan pembuatan produk tersebut yang terdiri dari alat dan

- bahan, cara pembuatan, dan anggaran dana (modal yang dibutuhkan dan laba yang akan dihasilkan ketika produk tersebut dijual)

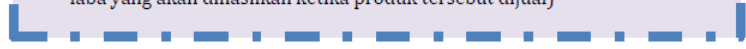

\section{Gambar 4 Tugas Kewirausahaan Lilin Aromaterapi}

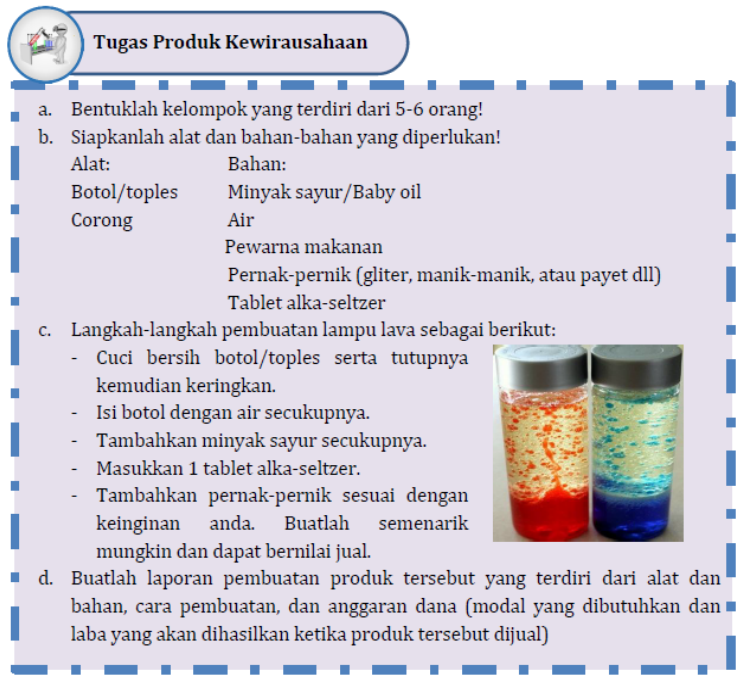

Gambar 5 Tugas Kewirausahaan Lampu Lava

Rangkuman materi yang disajikan dalam buku siswa bermuatan CEP bertujuan untuk memudahkan siswa mengetahui bagianbagian penting yang terdapat dalam bahan ajar berupa buku siswa. Kolom praktikum kimia berperan sebagai alat bantu/petunjuk dalam menguji materi melalui praktikum di laboratorium dan info kimia untuk menambah wawasan siswa mengenai keterkaitan kimia dengan kehidupan sehari-hari. Selain itu, di dalam buku siswa bermuatan CEP juga disisipkan kolom info kimia yang salah satu contohnya dapat dilihat pada Gambar 6.

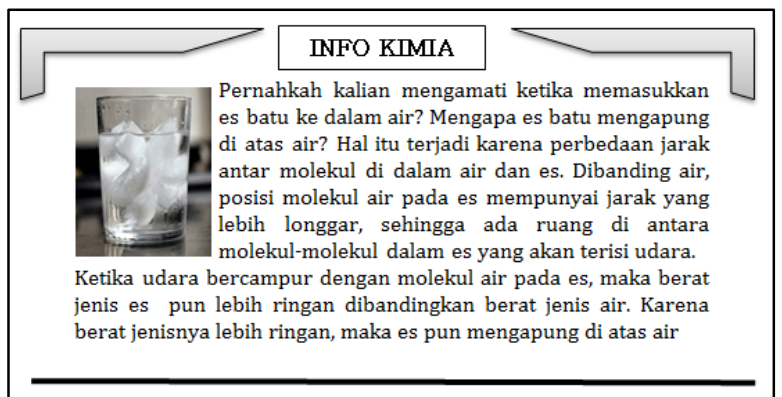

Gambar 6. Kolom Info Kimia

Soal evaluasi terdiri dari soal ulangan harian, soal pengayaan, dan soal remedial. Soal ulangan harian bertujuan untuk mengevaluasi hasil belajar siswa tentang materi ikatan kimia. Soal pengayaan bertujuan untuk pemantapan materi dan soal remedial digunakan untuk siswa yang belum lulus dalam soal ulangan harian.Bagian penutup berisi glosarium dan daftar pustaka yang digunakan dalam pembuatan buku siswa.

Pada tahap development (pengembangan), buku siswa yang akan dikembangkan divalidasi oleh satu orang ahli materi, satu orang ahli media, tiga orang peer review (teman sejawat), dan empat orang reviewer (guru kimia SMA/MA). Penilaian kualitas produk bahan ajar berupa buku siswa oleh reviewer (guru kimia SMA/MA) dilakukan dengan pengisian lembar penilaian kualitas kemudian diubah ke dalam data kuantitatif lalu ditabulasi dan dianalisis untuk menentukan kualitas buku siswa berorientasi Chemo-Entrepreneurship (CEP) materi ikatan kimia yang terbagi menjadi 6 aspek. Adapun 6 aspek penilaian yang digunakan meliputi aspek kelayakan isi/materi, aspek kelayakan bahasa, aspek penyajian, aspek kegrafikan, aspek karakteristik buku siswa, dan aspek pendekatan Chemo-Entrepreneurship (CEP), yang dijabarkan menjadi 19 indikator. Data hasil penilaian oleh reviewer (guru kimia SMA/MA) dapat dilihat pada Tabel 1. 
Tabel 1. Hasil Analisis Penilaian Bahan Ajar Berupa Buku Siswa Berorientasi ChemoEntrepreneurship (CEP) Menurut Reviewer (Guru Kimia SMA/MA)

\begin{tabular}{|c|l|c|c|c|c|c|}
\hline No & Aspek Penilaian & $\sum_{\text {Skor }}$ & $\begin{array}{c}\sum \text { Skor } \\
\text { Maks. Ideal }\end{array}$ & $\begin{array}{c}\text { Rata- } \\
\text { Rata }\end{array}$ & $\begin{array}{c}\text { Persentase } \\
\text { Keidealan (\%) }\end{array}$ & Kategori \\
\hline 1 & Kelayakan Isi/Materi & 53 & 15 & 13,25 & 88,33 & SB \\
\hline 2 & Kelayakan Bahasa & 68 & 20 & 17 & 85 & SB \\
\hline 3 & Penyajian & 53 & 15 & 13,25 & 88,33 & SB \\
\hline 4 & Kegrafikaan & 35 & 10 & 8,75 & 87,5 & SB \\
\hline 5 & Karakteristik Buku Siswa & 68 & 20 & 17 & 85 & SB \\
\hline 6 & Pendekatan CEP & 51 & 15 & 12,75 & 85 & SB \\
\hline & Keseluruhan & $\mathbf{3 2 8}$ & $\mathbf{9 5}$ & $\mathbf{8 2}$ & $\mathbf{8 6 , 3 2}$ & SB \\
\hline
\end{tabular}

Berdasarkan tabel di atas menunjukkan bahwa aspek kelayakan isi/materi, aspek kelayakan bahasa, aspek penyajian, aspek kegrafikaan, aspek karakteristik buku siswa, dan aspek pendekatan Chemo-entrepreneurship (CEP) dikategorikan sangat baik dengan persentase keidealan berturut-turut sebesar $88,33 \%, 85 \%$, $88,33 \%, 87,5 \%$, 85\%, dan 85\%. Persentase keidealan bahan ajar berupa buku siswa secara keseluruhan sebesar 86,32\% dengan kategori sangat baik atau layak untuk diujicobakan ke siswa SMA/MA dalam proses pembelajaran ikatan kimia. Buku siswa yang dikembangkan juga direspon oleh 10 siswa SMA/MA yang dapat dilihat pada Tabel 2 .

Tabel 2. Hasil Analisis Respon Siswa Terhadap Bahan Ajar Berupa Buku Siswa

\begin{tabular}{|l|c|c|c|c|}
\hline \multicolumn{1}{|c|}{ Aspek } & $\begin{array}{c}\text { Jumlah } \\
\text { Indikator }\end{array}$ & $\begin{array}{c}\text { Skor Rata- } \\
\text { rata }\end{array}$ & $\begin{array}{c}\text { Skor Maksimal } \\
\text { Ideal }\end{array}$ & $\begin{array}{c}\text { Persentase } \\
\text { Keidealan }\end{array}$ \\
\hline Materi & 2 & 1,8 & 2 & $90 \%$ \\
\hline Bahasa & 2 & 2 & 2 & $100 \%$ \\
\hline Penyajian & 2 & 2 & 2 & $100 \%$ \\
\hline Pendekatan CEP & 2 & 1,8 & 2 & $90 \%$ \\
\hline Kegrafikaan & 2 & 2 & 2 & $100 \%$ \\
\hline Keseluruhan & $\mathbf{1 0}$ & $\mathbf{9 , 6}$ & $\mathbf{1 0}$ & $\mathbf{9 6 \%}$ \\
\hline
\end{tabular}

Persentase keidealan bahan ajar berupa buku siswa berdasarkan respon siswa untuk aspek materi, aspek bahasa, aspek penyajian, pendekatan CEP, dan kegrafikaan sebesar $90 \%$, $100 \%$, 100\%, 90\%, dan 100\%. Persentase keidealan secara keseluruhan sebesar 96\% artinya buku siswa yang dikembangkan sangat baik menurut penilaian siswa SMA/MA.

Adapun masukan dan saran dari reviewer (guru kimia SMA/MA) dan siswa yaitu penulisan struktur Lewis masih ada yang perlu diperbaiki, banyak penulisan kata yang belum tepat, pada desain isi buku masih ada ruang yang kosong dapat ditambahkan gambar-gambar atau infoinfo yang berkaitan dengan materi, tambahkan penjelasan mengenai konfigurasi elektron, sebaiknya indikator pencapaian diletakkan pada awal saja, dan beberapa soal perlu diganti redaksinya.

\section{KESIMPULAN}

Karakteristik bahan ajar berupa buku siswa yang dikembangkan yaitu terdiri atas 3 subbab yaitu ikatan kimia, geometri molekul, dan interaksi antarmolekul. Dalam buku dilengkapi dengan tugas kewirusahaan seperti pembuatan media MEC Bond yang berkaitan dengan materi ikatan kimia, lilin aromaterapi yang berkaitan dengan gaya antarmolekul, dan lampu lava yang berkaitan dengan kepolaran senyawa. Hasil penilaian dari empat reviewer (guru kimia SMA/MA) memperoleh skor ratarata 82 dari skor maksimal 95 dengan persentase keidealan $86,32 \%$ dan termasuk 
kategori Sangat Baik (SB) sedangkan dari respon siswa memperoleh persentase keidealan $90 \%$ dengan kategori sangat baik. Dari hasil tersebut dapat disimpulkan buku siswa yang dikembangkan sangat baik atau layak digunakan untuk proses pembelajaran di SMA/MA pada materi ikatan kimia. Buku siswa yang telah dikembangkan perlu diujicobakan dalam proses pembelajaran untuk mengetahui sejauh mana kekurangan dan kelebihan buku tersebut. Selain itu, perlu dikembangkan penelitian yang sejenis dengan bentuk pengembangan yang berbeda semisal mengaitkan materi kimia yang lain dengan konsep kewirausahaan. 


\section{DAFTAR PUSTAKA}

Arsyad, A. (2011). Media Pembelajaran. Jakarta: PT. Rajagrafindo Persada.

Chang, R. (2005). Kimia Dasar Konsep - Konsep Inti Edisi Ketiga Jilid. Jakarta: Erlangga.

Ciputra. (2008). Quantum Leap $1^{\text {ed }}$. Jakarta : Elex Media.

Daryanto.(2010). Media Pembelajaran. Yogyakarta: Gava Media.

Haris, Mukhtar \& Wahidah, S. (2007). Analisis Kesulitan Belajar Ikatan Kimia Ditinjau dari Kesalahan Konsep Siswa Kelas X SMA Negeri 3 Mataram. Jurnal Pijar MIPA, 6(2).

Isnanto, D. (2016). Pengembangan Lembar Kerja Siswa Berbasis Pendekatan Pembelajaran Contextual Teaching and Learning (CTL) Materi Pokok Kegiatan Ekonomi di Indonesia Siswa Kelas V SD. Skripsi, Universitas Negeri Yogyakarta.

Kuratko, D. F. (2005). The Emergence of Entrepreneurship Education: Development, Trends, and Chalengges, Entrepreneurship Theory and Practice, 29(5): 577-598.

Kusuma,

$\mathrm{H}$ (2018).

(https://finance.detik.com/beritaekonomi-bisnis/d4009017/pengangguran-ri-687-jutaorang-paling-banyak-lulusan-smk), diakses pada 06 November 2018.

Nugroho, A. (2015). Pengembangan Lembar Kerja Siswa Berbasis Pendekatan Pembelajaran Contextual Teaching And Learning (CTL) Materi Pokok Kegiatan Ekonomi Di Indonesia Siswa Kelas V SD. Skripsi: Program Studi Pendidikan Guru Sekolah Dasar Jurusan Pendidikan Sekolah Dasar Fakultas Ilmu Pendidikan Universitas Negeri Yogyakarta.

Parwathi, P. L. S., Santiyadnya, N. \& Adiarta, A. (2017).Keterampilan Guru Dalam Mengelola Kelas Pada Pembelajaran
Prakarya Dan Kewirausahaan Di Sma Negeri 1 Singaraja. Jurnal Pendidikan Teknologi dan Kejuruan Vol. 14, No. 2, Juli 2017, Hal : 188 P-ISSN : 0216-3241; E-ISSN : 2541-0652 Fakultas Teknik dan Kejuruan, Universitas Pendidikan Ganesha.

Prayitno, Agus, dkk. (2016). Pengembangan Modul Pembelajaran Kimia Bervisi SETS Beriorientasi Chemo-Entrepreneurship (CEP) pada Materi Larutan Asam Basa. Jurnal Inovasi Pendidikan Kimia, 10(12), 1617 - 1628.

Putri, N. K. N., Danial, Muhammad, \& Arsyad, Nurdin. (2018). Pengaruh Sikap, konsep Diri, dan kesadaran Metakognitif terhadap Hasil Belajar Kimia Peserta Didik Kelas XI MIA SMAN di Kecamatan Ujung Bulu Kabupaten Bukukumba. Chemistry Education Review, 1(2).

Rachmawati, W. S. (2004).Anatomi Buku Ajar. Jakarta: Departemen Pendidikan Nasional.

Sugiyono. (2012). Metode Penelitian Kuantitatif Kualitatif dan R\&D. Bandung: Alfabeta.

Sukardjo dan Sari, L. P. (2008). Metodologi Penelitian Pendidikan Kimia. Yogyakarta: FMIPA UNY.

Supartono. (2006). Peningkatan Kreativitas Peserta Didik Melalui Pembelajaran Kimia dengan Pendekatan Chemoentrepreneurship (CEP). Proposal Research Grant - Program Hibah A2. Semarang: Jurusan Kimia FMIPA UNNES.

Soemanto, W. (2006). Psikologi pendidikan (landasan kerja pemimpin pendidikan). Jakarta: Rineka Cipta.

Tohani, E. (2015). Dampak Pendidikan Kewirausahaan Masyarakat (Pkum) Dalam Konteks Pemberdayaan Masyarakat. Jurnal Ilmiah VISI PPTK PAUDN/ 10(1). 
Trianto. (2012). Character Building, Optimalisasi Peran Pendidikan dalam Pengembangan Ilmu dan Pembentukan Karakter Bangsa. Yogyakarta: Ar-ruzz Media.

Widada, R. U. W. (2012). Pengelolaan Pendidikan Kecakapan Hidup Pada Program Keahlian Pemasaran (Studi Situs SMK Negeri 2 Magelang). Naskah Publikasi Program Studi Magister Manajemen Pendidikan Universitas Muhammadiyah Surakarta.

Widoyoko, S. (2011). Evaluasi Program Pembelajaran. Yogyakarta: Pustaka Pelajar.

Winarno. (2011). Pengembangan Sikap Entrepreneurship dan Intrapreneurship. Jakarta: PT. Indeks. 